\title{
Patient's Perception and Attitude of Pharmacist during Pharmacy Visits in Saudi Arabia
}

\author{
Yousef Ahmed Alomi ${ }^{1}$, ${ }^{\mathbb{D}}$, Sarah Abdullah Al-Hathlool ${ }^{2}$, Maryam Ibrahim Almulhim ${ }^{3}$, Amal Ali \\ Alashaq ${ }^{2}$, Yousef Aboshalaf ${ }^{3}$, Mytham Al-Ethan ${ }^{4}$ \\ ${ }^{1}$ The Past General Manager of General Administration of Pharmaceutical Care, the past head, National Clinical \\ Pharmacy and Pharmacy Practice, the past head, Pharmacy R and D Administration, Ministry of Health, Riyadh, Saudi \\ Arabia \\ ${ }^{2}$ Clinical Pharmacy Staff, General Administration of Pharmaceutical Care, Ministry of Health, Riyadh, Saudi Arabia. \\ ${ }^{3}$ Head of Pharmacy Services King Fahad Hospital, Alhasa, Saudi Arabia. \\ ${ }^{4}$ Assistant head of Pharmacy Services, King Fahad Hospital, Alhasa, Saudi Arabia.
}

\begin{abstract}
Purpose: To explore patient's perception and attitude during pharmacy visit in Saudi Arabia. Methods: This is a 4-month cross-sectional survey of patient perception regarding pharmacists. The survey consisted of two parts: the first part captures demographic information and the second part is a questionnaire with 49 questions divided into four domains: (1) The first domain is regarding patient's general perception of the pharmacist; (2) the second domain captures data of patient's perception regarding pharmaceutical care services; (3) the third domain is regarding patient's perception of visiting ambulatory care; and (4) the fourth domain captures information on patient's perception regarding the pharmacist's relationship and counseling skills. We used the 5-point Likert response scale system to obtain responses of the participants. There were open- and close-ended questions. The survey was distributed through social media to a 500-bed general hospital in Alhassa region, an ambulatory care pharmacy. The authors interviewed the patients with an electronic survey documentation. The survey analyzed domain three, which is about the patient's perception of visiting ambulatory care through Survey Monkey system. Results: A total of 617 patients responded to the survey. Of them, $536(87.7 \%)$ were Saudi and 75 (12.3\%) were non-Saudi nationals. There were $457(74.1 \%)$ female and 160 (25.9\%) male responders. In the past 12 months, most of the patients (222 (36\%)) visited the pharmacy more than 10 times, whereas the others (122 (19.8\%)) visited the pharmacy at least 5-9 times. Most of the patients (481 (83.5\%)) spent less than 11 min with the pharmacist. The average score of patients' general perception of the pharmacist during pharmacy visit was 3.74. The highest score was obtained for the statements received all medications prescribed to me (4.16) and pharmacy convenient located (4.0). ${ }^{4}$ The lowest score was obtained for the statement pharmacy waiting area convenient located (3.38). The average score of patient perception of the pharmacist with drug monitoring during the pharmacy visit was 3.74. The highest score was obtained for the statement-the patient revived a copy of prescription-contained medications (3.4), whereas the lowest score was obtained for the statement-the pharmacist gives a follow-up call to the patient as medications prescribed (2.09). The score for general evaluation of pharmacy visit was found to be 3.67 with a score of (3.55) for the preference to visit the pharmacy or recommendation to other patients or friends. Conclusion: According to our results, patient's perception during pharmacy visit was found to be acceptable. Pharmacy communication methods and counseling place missed. Corrections of patient needs will improve patient's perceptions and raise patient satisfaction during visiting of pharmacy.

Key words: Patient, Perception, Attitude, Visit, Ministry of Health, Saudi Arabia.
\end{abstract}

Received: 03-07-2018;

Accepted: 01-09-2018

*Correspondence to:

Dr. Yousef Ahmed Alomi Email: yalomi@gmail.com DOI: $10.5530 /$ ijpcs.2018.7.8

Copyright: ๑ the author(s),publisher and licensee International Journal of Pharmacology and Clinical Sciences. This is an open-access article distributed under the terms of the Creative

Commons Attribution Non-Commercial License, which permits unrestricted non-commercial use, distribution, and reproduction in any medium, provided the original work is properly cited.

This is an open access article distributed under the terms of the Creative Commons AttributionNonCommercial-ShareAlike 4.0 License

Access this article online

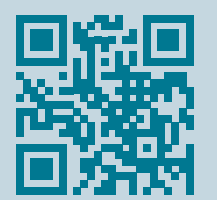

www.ijpcs.net 


\section{INTRODUCTION}

The patient visits an ambulatory care clinic in search for medical care. Several healthcare professionals provide the services to the patient to improve the clinical outcome of the patient during treatment or prevention of the disease. Each service had different tools with different levels of healthcare services. One of the tools of measurements is to measure the satisfaction of services provided by healthcare professionals including physicians, nurses, and pharmacists. ${ }^{1} \mathrm{~A}$ previous study has been published regarding the satisfaction of pharmacy services. ${ }^{2}$ There is another tool of measurement called perception of the patient while providing the services. There are several studies that have discussed on the patients' perception of the pharmacist and their attitude during their visit to the ambulatory care pharmacy or community pharmacy. ${ }^{3-5}$ However, to the best of our knowledge, the studies regarding the patient perception of a pharmacist during receiving ambulatory care services are scarce worldwide. ${ }^{6}$ Therefore, in this study, we aimed to explore the patient's perception of a pharmacist during receiving ambulatory care service in Kingdom of Saudi Arabia.

\section{METHODS}

This is a 4-month cross-sectional survey of patient perception regarding pharmacists. The survey consisted of two parts: the first part captures demographic information and the second part is a questionnaire with 49 questions divided into four domains: (1)the first domain captures data on patient's general perception of the pharmacist; (2) the second domain is regarding patient's perception of pharmaceutical care services; (3) the third domain is related to the patient's perception of visiting ambulatory care; and (4) the fourth domain is related to the patient's perception of pharmacist's relationship and counseling skills. We used the 5-point Likert response scale system to obtain responses of patients. There were open- and close-ended questions. The survey was distributed through social media at a 500-bed general hospital in Alhassa region, an ambulatory care pharmacy. The hospital is accredited to the Central Board for Accreditation of Healthcare Institutions (CBAHI) in Saudi Arabia and to the Joint Commission on Hospital Accreditation in the United States of America (USA). ${ }^{7-8}$ The hospital has several departments including the adults' internal medicine, adults' surgery, pediatrics, obstetrics and gynecology. It had adults, pediatrics, and neonatal critical care units with a separate nursing unit, in addition to the medical and surgical ambulatory care clinics. The pharmacy departments distribute the medication through unit dose system according to CBAHI standards and American Society of Health-System standards. Furthermore, the pharmacy had inpatient pharmacy, outpatient pharmacy, intravenous admixture services with professional total parenteral nutrition. The clinical pharmacy services cover critical care units, internal medicine, drug information center, patient-counseling services, and medication safety programs. The authors interviewed the patients with an electronic survey documentation. The survey analyzed domain one, which is patient's perception of a pharmacist during receiving ambulatory care service in Kingdom of Saudi Arabia.

\section{RESULTS}

A total of 617 patients responded to the survey. Of them, $536(87.7 \%)$ were Saudi and 75 (12.3\%) were nonSaudi nationals. There were 457 (74.1\%) female and 160 (25.9\%) male responders. Most of them were in the age group of 18-44 years (84.1\%) and were located at Alhasa Region (255 (41.7\%)), Riyadh Region (150 (24.55\%)), and East Province region (144 (23.56\%)). The highest level of education of the responders was Bachelor's degree (395 (64.4\%)) followed by high school level (95 $(15.5 \%))$. In the past 12 months, most of the patients (222 (36\%)) visited the pharmacy more than 10 times, whereas the others (122(19.8\%)) visited the pharmacy at least 5-9 times. Most of the patients had visited due to their follow-up visit (192 81.70\%), whereas for other (43 (18.30\%)), this was their first visit. Most of the patients $(395(64.6 \%))$ visited the pharmacy at evening. Most of the patients $(481(83.5 \%))$ spent less than 11 min with the pharmacist (Table 1 ). The average score of patient's general perception of a pharmacist during pharmacy visit was found to be 3.74. The statements such as received all medications prescribed to me (4.16) and pharmacy is conveniently located (4.0) obtained the highest scores. ${ }^{4}$ The statement that obtained lowest score was pharmacy's waiting area is conveniently located (3.38). The average score of patient's perception of the pharmacist with drug monitoring during their pharmacy visit was found to be 3.74 ; the statement with highest score was-the patient revived a copy of prescription-contained medications (3.4), whereas the statement with the lowest score was-the pharmacist gives follow-up call to the patients as medications prescribed (2.09). The score on general evaluation of pharmacy visit was 3.67 with a preference to visit the pharmacy or recommend it to the other patients or 


\begin{tabular}{|c|c|c|}
\hline & Response Count & Response Percent \\
\hline \multicolumn{3}{|l|}{ Sex } \\
\hline Female & 457 & $74.07 \%$ \\
\hline Male & 160 & $25.93 \%$ \\
\hline Answered question & 617 & \\
\hline Skipped question & 0 & \\
\hline \multicolumn{3}{|l|}{ Nationality } \\
\hline Saudi & 536 & $87.73 \%$ \\
\hline Non-Saudi & 75 & $12.27 \%$ \\
\hline Answered question & 611 & \\
\hline Skipped question & 6 & \\
\hline \multicolumn{3}{|l|}{ Age } \\
\hline$<18$ & 35 & $5.69 \%$ \\
\hline $18-29$ & 277 & $45.04 \%$ \\
\hline $30-44$ & 240 & $39.02 \%$ \\
\hline $45-59$ & 60 & $9.76 \%$ \\
\hline $60+$ & 3 & $0.49 \%$ \\
\hline Answered question & 615 & \\
\hline Skipped question & 2 & \\
\hline Type of visit & Response Count & Response Percent \\
\hline First visit & 43 & $18.30 \%$ \\
\hline Follow up & 192 & $81.70 \%$ \\
\hline Answered question & 235 & \\
\hline Skipped question & 2 & \\
\hline $\begin{array}{l}\text { In the last } 12 \text { months, the number of times visited the } \\
\text { pharmacy }\end{array}$ & Response Count & Response Percent \\
\hline None & 23 & $3.73 \%$ \\
\hline 1 time & 40 & $6.49 \%$ \\
\hline 2 & 60 & $9.74 \%$ \\
\hline 3 & 56 & $9.09 \%$ \\
\hline 4 & 93 & $15.10 \%$ \\
\hline 5 to 9 & 122 & $19.81 \%$ \\
\hline 10 or more times & 222 & $36.04 \%$ \\
\hline Answered question & 616 & \\
\hline Skipped question & 1 & \\
\hline Time of Visiting the Pharmacy & Response Count & Response Percent \\
\hline Morning & 116 & $18.99 \%$ \\
\hline Evening & 395 & $64.65 \%$ \\
\hline Night & 100 & $16.37 \%$ \\
\hline Answered question & 611 & \\
\hline Skipped question & 6 & \\
\hline The waiting time to get the medications & Response Count & Response Percent \\
\hline$<5$ & 293 & $50.87 \%$ \\
\hline 5-10 & 188 & $32.64 \%$ \\
\hline $11-15$ & 53 & $9.20 \%$ \\
\hline $16-20$ & 17 & $2.95 \%$ \\
\hline
\end{tabular}


Alomi, et al.: Patient's Perception during Pharmacy Visits in Saudi Arabia

\begin{tabular}{|c|c|c|}
\hline $21-25$ & 4 & $0.69 \%$ \\
\hline $26-30$ & 10 & $1.74 \%$ \\
\hline $31-35$ & 1 & $0.17 \%$ \\
\hline $36-40$ & 2 & $0.35 \%$ \\
\hline $41-45$ & 3 & $0.52 \%$ \\
\hline $46-50$ & 0 & $0.00 \%$ \\
\hline $51-55$ & 1 & $0.17 \%$ \\
\hline $56-60$ & 1 & $0.17 \%$ \\
\hline more than 60 years or equal & 3 & $0.52 \%$ \\
\hline Answered question & 576 & \\
\hline Skipped question & 41 & \\
\hline Educational levels & Response Count & Response Percent \\
\hline Doctorate degree & 10 & $1.63 \%$ \\
\hline Master degree & 32 & $5.22 \%$ \\
\hline Bachelor Degree & 395 & $64.44 \%$ \\
\hline Diploma & 46 & $7.50 \%$ \\
\hline High school & 95 & $15.50 \%$ \\
\hline Intermediate School & 29 & $4.73 \%$ \\
\hline Primary School & 5 & $0.82 \%$ \\
\hline Not educated & 1 & $0.16 \%$ \\
\hline Answered question & 613 & \\
\hline Skipped question & 4 & \\
\hline
\end{tabular}

\section{Table 2: The General Patients Perception toward the pharmacist during his visiting during his visiting.}

\begin{tabular}{|c|c|c|c|c|c|c|c|}
\hline Answer Options & $\begin{array}{l}\text { Strongly } \\
\text { agree }\end{array}$ & Agree & Neutral & Disagree & $\begin{array}{l}\text { Strongly } \\
\text { disagree }\end{array}$ & $\begin{array}{l}\text { Rating } \\
\text { Average }\end{array}$ & $\begin{array}{c}\text { Response } \\
\text { Count }\end{array}$ \\
\hline $\begin{array}{l}\text { 1. Pharmacy Location Domain } \\
\text { Is the pharmacy conveniently located }\end{array}$ & 163 & 278 & 84 & 21 & 13 & 4.00 & 559 \\
\hline $\begin{array}{l}\text { 2. Pharmacy Waiting Area Domain } \\
\text { Is the waiting area of pharmacy conveniently } \\
\text { located? }\end{array}$ & 84 & 212 & 137 & 82 & 43 & 3.38 & 558 \\
\hline $\begin{array}{l}\text { 3. Pharmacy Waiting Time Domain } \\
\text { The amount of time it takes to get a } \\
\text { prescription filled at your pharmacy is } \\
\text { very appropriate. }\end{array}$ & 107 & 283 & 110 & 44 & 15 & 3.76 & 559 \\
\hline $\begin{array}{l}\text { 4. Medication Availability Domain } \\
\text { Have you received all the medications, that has } \\
\text { prescribed to you }\end{array}$ & 216 & 275 & 64 & 21 & 6 & 4.16 & 582 \\
\hline $\begin{array}{l}\text { 5. You have received a prescription refill of } \\
\text { your medicines to continue dispensing from } \\
\text { pharmacy directly next months. }\end{array}$ & 89 & 200 & 173 & 74 & 37 & 3.40 & 573 \\
\hline answered question & & & & & & & 565 \\
\hline skipped question & & & & & & & 52 \\
\hline
\end{tabular}




\begin{tabular}{|c|c|c|c|c|c|c|c|}
\hline Answer Options & $\begin{array}{l}\text { Strongly } \\
\text { agree }\end{array}$ & Agree & Neutral & Disagree & $\begin{array}{l}\text { Strongly } \\
\text { disagree }\end{array}$ & $\begin{array}{l}\text { Rating } \\
\text { Average }\end{array}$ & $\begin{array}{l}\text { Response } \\
\text { Count }\end{array}$ \\
\hline $\begin{array}{l}\text { 1. Medication Reconciliation Domain } \\
\text { Pharmacist uses information about you } \\
\text { previous conditions/drugs when assessing your } \\
\text { drug therapy. }\end{array}$ & 82 & 129 & 139 & 150 & 65 & 3.02 & 565 \\
\hline $\begin{array}{l}\text { 2. You have received a copy of prescription } \\
\text { contains all medications prescribed to you, and } \\
\text { may use during outpatient clinic or emergency } \\
\text { when necessary. }\end{array}$ & 82 & 206 & 141 & 83 & 34 & 3.40 & 546 \\
\hline $\begin{array}{l}\text { 3. Medication Adherence Domain } \\
\text { The pharmacist asks about medication } \\
\text { compliance }\end{array}$ & 53 & 109 & 156 & 162 & 80 & 2.81 & 560 \\
\hline $\begin{array}{l}\text { 4. The pharmacist follow up you and call you } \\
\text { after taking your medications as prescribed }\end{array}$ & 29 & 41 & 110 & 153 & 227 & 2.09 & 560 \\
\hline $\begin{array}{l}\text { 5. Pharmacy Recommended to other patients } \\
\text { Domain Prefer to visit the pharmacy again or } \\
\text { recommend to your brothers or friends }\end{array}$ & 82 & 225 & 176 & 57 & 14 & 3.55 & 554 \\
\hline $\begin{array}{l}\text { 6. Overall Patient Satisfaction with Pharmacy } \\
\text { Services Domain: } \\
\text { Your general evaluation for the pharmaceutical } \\
\text { care is very satisfied }\end{array}$ & 92 & 259 & 153 & 34 & 18 & 3.67 & 556 \\
\hline \multicolumn{7}{|l|}{ answered question } & 565 \\
\hline \multicolumn{7}{|l|}{ skipped question } & 52 \\
\hline
\end{tabular}

friends of 3.55 (Tables 2 and 3).

\section{DISCUSSION}

The pharmacy administration in Ministry of Health in the Kingdom of Saudi Arabia established the updated pharmaceutical care strategic plan. ${ }^{9}$ The pharmacy plan needs some key performance indicators to measure the level of success of the implementation process. Several pharmacy indicators established for each plan, for instance, in the medications safety part, the indicators were a score of Institute for Safe Medication Practices (ISMP) self-assessment of medications safety at the hospital. ${ }^{10}$ The indicator for the pharmacy plan of the national drug information centers was the cost avoidance of answering information inquiries. ${ }^{11}$ The indicator for the ambulatory care pharmacy was the patient satisfaction with pharmacy services. ${ }^{1,12}$ However, the patient's perception of a pharmacist during pharmacy visit is another tool of strategic plan measurement. In this study, the authors aimed to explore the patients' perception of the pharmacist during their visit to the ambulatory care pharmacy. According to our results, the patient's perception of the pharmacist during pharmacy visit was not adequate with an average score of less than four. The highest score was related to-the patient received most of the medications and pharmacy location was appropriate for the patient. This was related to the Saudi and Food
Drug Authority (SFDA) requirements from all the pharmaceutical companies for their medications, which should be on the market after complete registration. Furthermore, some pharmacists have implemented the inventory management system for the medications. The pharmacist plays a proper role in marketing the services of community pharmacies. The pharmacists perform systematic evaluation while choosing the pharmacy location. Thus, we can find a chain of pharmacy. Despite this, the score for appropriate location of the waiting area in the pharmacy was the lowest. Majority of pharmacies do not have an appropriate waiting area, especially in community pharmacies. This shows that the patient's perception with drug monitoring during pharmacy visit is inadequate. The reconciliation of medications obtained the highest scores as some pharmacies had an electronic prescription with a copy given to the patient, whereas other pharmacies did not have such a system. The finding agrees with those reported by Al-Arifi and by Oshima et al. ${ }^{6,13}$ The medication adherence system did not exist at most of the pharmacies. This system is absent in most of the hospitals or in community pharmacies. There are no tools available to establish medication adherence services, for instance, training programs, policies and procedures, computerized physician's order entry, and unified patient medical records. Our results with respect to the medication adherence were found to be lower than those reported by Al-Arifi. ${ }^{6}$ this is because, 
in our study, the community and hospital pharmacies were included as responders, whereas in Al-Arifi's study, community pharmacy visitors were included as responders. Our study might actually reflect more on the real situation. Although the several most of patient's perception was found within average; the overall pharmacy evaluation was acceptable. Also, the patients recommended the pharmacy to visit by their families or friends. The getting high scores in the perceptions maybe due to the good communication skills of the pharmacist and patient counseling services provided by some pharmacists.

\section{CONCLUSION}

The patient's perception of a pharmacist during pharmacy visit was found to be neutral despite some factors being missed related to drug therapy monitoring. Targeting to improve the medication non adherence and reconciliation are highly recommended to improve patient's perception of pharmacist during pharmacy visit in the Kingdom of Saudi Arabia.

\section{ACKNOWLEDGMENT}

None.

\section{CONFLICT OF INTEREST}

None.

\section{ABBREVIATIONS}

KSA: Kingdom of Saudi Arabia; MOH: Ministry of Health; CBAHI: Saudi Central Board for Accreditation of Healthcare Institutions; ASHP: American Society of Health-System; USA: United States of America; ISMP: Institute for Safe Medication Practices; SFDA: Saudi and Food Drug Authority.

\section{ORCID ID}

Yousef Ahmed Alomi (D) https://orcid.org/0000-00031381-628X

\section{REFERENCES}

1. Alomi YA. Patient satisfaction of pharmaceutical care system at Ministry of Health in Saudi Arabia. BAOJ Pharm Sci. 2016;2:19.

2. Alomi YA, Kurdy L, Aljarad Z, Basudan H, Almekwar B. Patient satisfaction of pharmaceutical care of primary care centers at Ministry of Health in Saudi Arabia. J Pharm Pract Community Med. 2016;2(3):79-87.

3. Merks P, Świeczkowski D, Jaguszewski MJ. Patients' perception of pharmaceutical services available in a community pharmacy among patients living in a rural area of the United Kingdom. Pharm Pract (Granada). 2016;14(3)

4. Khan MU, Khan AN, Ahmed FR, Feroz Z, Rizvi SA, Shah S, et al. Patients opinion of pharmacists and their roles in health care system in Pakistan. J Young Pharm. 2013;5(3):90-4.

5. Shiyanbola OO, Mott DA, Croes KD. The structural and process aspects of pharmacy quality: older adults' perceptions. Int J Clin Pharm. 2016;38(1):96-106.

6. Al-Arifi MN. Patients' perception, views, and satisfaction with pharmacists' role as health care provider in a community pharmacy setting at Riyadh, Saudi Arabia. Saudi Pharm J. 2012;20(4):323-30.

7. Medication Management (MM). In: National Hospital Standards. 2nd Edition. Saudi Central Board for Accreditation of Healthcare Institutions; 2015.194-211. [cited 2017 Nov 12]. Available from: http://www.cbahi. gov.sa

8. The Joint Commission. Comprehensive Accreditation Manuals. Joint Commission Resources. [cited 2017 Nov 12]. Available from: http://www. jcrinc.com/store/publications/manuals/

9. Alomi YA, Alghamdi SJ, Alattyh RA. Strategic Plan of General Administration of Pharmaceutical Care at Ministry of Health in Saudi Arabia 2012-2022. JPharm Pharm Scien. 2015;1(13):1-8.

10. Institute for Safe Medication Practices. 2011 ISMP Medication Safety Self Assessment for Hospitals, Key Definitions. 2011;1-4. Available from: http://ismp.org/selfassessments/Hospital/2011/definitions.pdf

11. Alomi YA, Almudaiheem HY, Alarnous T, Alshurei S, Alsharafa A, Alzahrani $\mathrm{T}$, et al. Cost-Efficiency of National Drug Information Center Through Ministry of Health Hotline Calling Services (937) in Saudi Arabia: Application of American Model. Value Health. 2015;18(7):A735.

12. Alomi YA, Kurdy L, Aljarad Z, Basudan H, Almekwar B, Almahmood S. Patient satisfaction of pharmaceutical care of primary care centers at Ministry of Health in Saudi Arabia. J Pharm Pract Community Med. 2016;2(3).

13. Oshima S, Senoo K, Negishi A, Akimoto H, Kutsuma N, Juni K, et al. Identification of the Discrepancies between Pharmacist and Patient Perception of the Pharmacist's Role as an Advisor on Drug Therapy Based on Social Science Theory. Biol Pharm Bull. 2016;39(39):313-22. 